\title{
Paleo-environmental evidence of ecosystem change in Lake St. Clair region of Laurentian Great Lakes basin: contrasting responses to land-use change and invasive mussels
}

\author{
Melissa M. Baustian (1D - Yolanda M. Brooks - Mark Baskaran • \\ Peter R. Leavitt $(\mathbb{D} \cdot$ Bo Liu • Nathaniel Ostrom - R. Jan Stevenson • \\ Joan B. Rose
}

Received: 15 April 2018/Accepted: 23 December 2019/Published online: 23 January 2020

(C) The Author(s) 2020

\begin{abstract}
The Laurentian Great Lakes have been subject to substantial modification from diverse anthropogenic stressors, including nutrient enrichment, climate change, chemical and biological pollutants, and invasive species, yet little is known of the relative historical influence of these factors. Here we analyze diverse fossil metrics from vibracores at two sites, a bay area (Anchor Bay) and a tributary (Clinton River) in the Lake St. Clair ecosystem to determine the ecological responses from land-use practices and invasive mussel invasions. Sediment cores spanning over 100 years indicated that the expansion of nonnative Dreissena polymorpha and Dreissena rostriformis (dreissenid mussels) into Anchor Bay site after the mid-1990s was associated with $\sim 60$ to $95 \%$
\end{abstract}

Electronic supplementary material The online version of this article (https://doi.org/10.1007/s10933-019-00108-x) contains supplementary material, which is available to authorized users.

M. M. Baustian · R. J. Stevenson - J. B. Rose

Center for Water Sciences, Michigan State University, 1405 S. Harrison Rd, Room 301, East Lansing, MI 48824, USA

e-mail: rjstev@msu.edu

J. B. Rose

e-mail: rosejo@msu.edu

M. M. Baustian ( $\square)$

The Water Institute of the Gulf, 1110 River Road South, Suite 200, Baton Rouge, LA 70802, USA

e-mail: mbaustian@thewaterinstitute.org reduction in algal and cyanobacterial abundances and twofold increase in sedimentary organic matter (SOM) and bioavailable phosphorus. These increases in SOM and bioavailable phosphorus are relatively similar to increases inferred from the late nineteenth century when large portions of the watershed were cleared and drained for agriculture. In contrast, the Clinton River site experienced a continuous increase in the influx of nutrients, organic matter, and elevated sedimentary phototrophic pigments during the twentieth century and into the twenty-first century. Site comparisons suggest different mechanisms inducing changes in primary production varied, where Anchor Bay was mainly affected by the comparatively recent (since ca. mid-1990s) endogenous influence of invasive species, while the Clinton River site was primarily influenced by the input of exogenous anthropogenic nutrients over the past 100 years. These new findings illustrate that watershed management and policies within large

\footnotetext{
Y. M. Brooks · J. B. Rose

Department of Microbiology and Molecular Genetics, Michigan State University, 567 Wilson Rd, Rm 2209,

East Lansing, MI 48824, USA

e-mail: brooksyo@msu.edu

M. Baskaran

Department of Geology, Wayne State University, Detroit, MI 48202, USA

e-mail: baskaran@wayne.edu
} 
lakes with multi-jurisdictional (national) Area of Concerns should consider site-specific regulatory mechanisms.

Keywords Paleolimnology $\cdot$ Sediments $\cdot$ Dreissenid mussels · Organic matter $\cdot$ Fossil pigments

\section{Introduction}

Aquatic ecosystems have experienced intense changes caused by human influences. Growth of human populations resulted in changes of land cover from forested ecosystems to urban settings or intense agriculture (Sanderson et al. 2002) that now depends on heavy nitrogen and phosphorus fertilizer use (Bennett et al. 2001; Vitousek et al. 1997). Runoff from agricultural lands, as well as diverse forms of wastewater treatment plants, have intensified high nitrogen and phosphorus inputs to rivers, lakes and coastal oceans that degrade water quality (Arbuckle and Downing 2001; Turner and Rabalais 1994). Consequently, nonpoint allochthonous nutrient sources are a powerful agent that impact global freshwaters (Carpenter et al. 1998; McCrackin et al. 2017).

\section{P. R. Leavitt}

Limnology Laboratory, and Institute of Environmental Change and Society, University of Regina, Regina, SK S4S0A2, Canada e-mail: peter.leavitt@uregina.ca; p.leavitt@qub.ac.uk URL: https://pure.qub.ac.uk/en/persons/peter-leavitt

\section{P. R. Leavitt}

Institute of Global Food Security, Queen's University Belfast, Belfast, Antrim BT9 5DL, UK

\section{B. Liu $\cdot$ N. Ostrom · R. J. Stevenson}

Department of Integrative Biology and Ecology and Evolutionary Biology and Behavior Program, Michigan State University, 288 Farm Lane, Room 203,

East Lansing, MI 48824, USA

e-mail: iocas_liubo@hotmail.com

N. Ostrom

e-mail: Ostromn@msu.edu

J. B. Rose

Department of Plant, Soil and Microbial Sciences, Michigan State University, 1066 Bogue Street, Room A286, East Lansing, MI 48824, USA
Humans have also facilitated the worldwide spread of non-indigenous species that in turn alter the structure and function of aquatic ecosystems (Higgins and Vander Zanden 2010; Pimentel et al. 2005). Large lentic aquatic ecosystems (i.e., lakes, bays, and estuaries of surface areas $>500 \mathrm{~km}^{2}$ ) may be particularly susceptible to the combined effects of land-use changes and invasive species. Bays and tributaries of large lakes have a long history of elevated nutrient loading (Beeton 1969; Savage et al. 2004; Schelske et al. 1983), and algal blooms (Harris and Vollenweider 1982; Levine et al. 2012) following profound changes in land use within their catchments. In addition, because of their prominence as a regional transportation hub, these large ecosystems are often subject to unusually intense colonization by diverse biological invaders (Hall and Mills 2000; Vanderploeg et al. 2002). In particular, non-native Dreissenia have colonized in many large lakes (Hall and Mills 2000; Higgins and Vander Zanden 2010) although their effects on water quality has not been uniform (Fahnenstiel et al. 1995; Higgins et al. 2011).

Lake St. Clair is a large $\left(1114 \mathrm{~km}^{2}\right)$ and shallow $($ mean $=3 \mathrm{~m}$ ) basin that connects the upper and lower Laurentian Great Lakes. The lake has been exposed to diverse exogenous and endogenous stressors in the past century (Baustian et al. 2014). Since 1988, Lake St. Clair is recognized as being the first site with established populations of non-indigenous Dreissena polymorpha (zebra mussels) in North America, approximately 3 years after their initial invasion (Griffiths et al. 1991; Vanderploeg et al. 2002). Subsequently, these bivalves (including Dreissena rostriformis, quagga mussels) have significantly altered the benthic and pelagic ecology of Lake St. Clair and adjacent freshwater ecosystems (Griffiths 1993; Nalepa et al. 1996; Vanderploeg et al. 2002). Additionally, expansion of the cities of Detroit (MI, USA) and Windsor (ONT, Canada) have resulted in concomitant agricultural development and suburbanization (Baustian et al. 2014).

Despite substantial environmental change, little ecological data is available until the 1970s to assess the relative impact of land use and invasive species on Lake St. Clair (Baustian et al. 2014; Leach 1972). To address this shortcoming, we quantified historical changes of multiple sedimentary proxies including fossil phototrophic pigments and sediment geochemistry at two sites to evaluate how increases in nutrients 
and invasive species have differentially influenced a tributary site and an open-water location. We built upon previous analyses of historical trends of fecal indicator bacteria by Brooks et al. (2016) to quantify historical ecological changes in the indicators of nutrient enrichment. We hypothesized that this aquatic ecosystem experienced site-specific responses to longterm land-use change and more recently, rapid colonization by non-native bivalves.

Study site

Lake St. Clair is located between oligotrophic Lake Huron to the north and meso-eutrophic Lake Erie to the southeast (Fig. 1) (Leach 1991). Overall, the lake exhibits relatively high-water quality (low nutrient and chlorophyll $a$ concentrations) because most of the water $(98 \%)$ comes from Lake Huron via the St. Clair River (Leach 1991; Vanderploeg et al. 2002; Baustian et al. 2014). Anchor Bay receives about $34 \%$ of the St. Clair River flow via the North Channel (Bolsenga and Herdendorf 1993) and the habitat consists of dense benthic macrophyte coverage that has been heavily colonized by $D$. polymorpha with lake mean mussel densities ranging between about 1800 and 3200 individuals $\mathrm{m}^{-2}$ in years between 1994 and 2001 (Hunter and Simons 2004; Nalepa et al. 1996). Conversely, the Clinton River is one of four tributaries of Lake St. Clair, and is located on the western coast (Fig. 1). There, the waters are turbid and eutrophic with extensive shoreline hardening structures (Mavrommati et al. 2013). This area has experienced a low degree of $D$. polymorpha colonization based on qualitative density estimates (Schloesser et al. 1996; Selegean et al. 2001). The Clinton River and its drainage basin $\left(\sim 1978 \mathrm{~km}^{2}\right)$ have been heavily altered by suburban development around metropolitan Detroit (Baustian et al. 2014; Mavrommati et al.

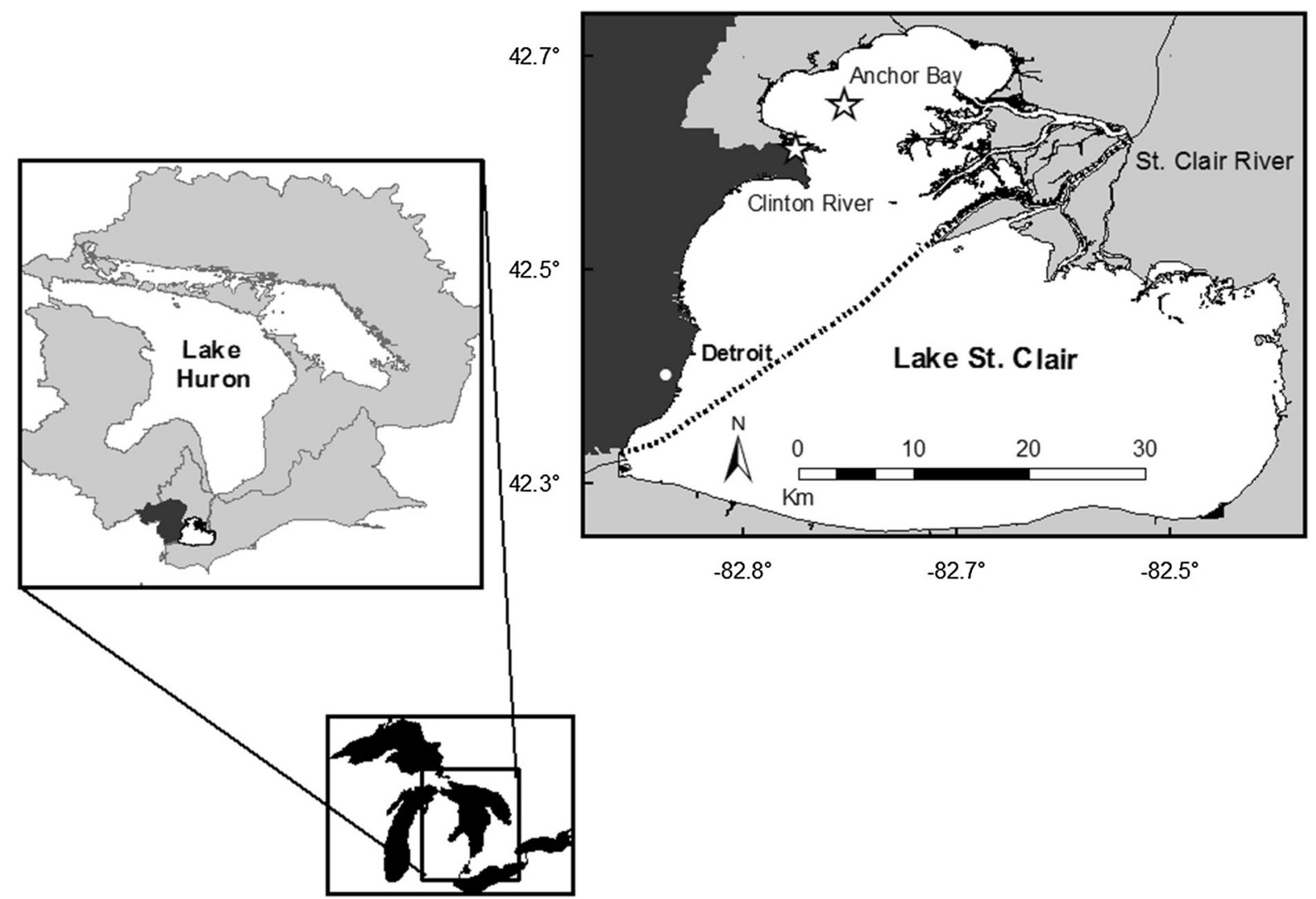

Fig. 1 Map of sediment core collection sites (stars) in Anchor Bay and of Clinton River (upper right map) in the western area of Lake St. Clair, Michigan, USA, part of the Laurentian Great Lakes system (lower left maps). Dashed line represents the shipping channel that is part of Great Lakes-St. Lawrence Seaway. Dark grey represents Clinton River basin and light grey is the Lake Huron basin and other areas of the Lake St. Clair basin 
2013). The watershed and river have been classified as an Area of Concern (AOC) since 1987 under the Great Lakes Water Quality Agreement (International Joint Commission 2006), reflecting local beneficial use impairments such as eutrophication or undesirable algae, beach closings due to fecal pollution, and degradation of fish and wildlife populations. Consequently, this area has been subject to considerable restoration plans and efforts among federal, state, and local institutions.

\section{Materials and methods}

Sediment core collection

Sediment vibracores were collected on 21 August 2012 at two sites; in Anchor Bay, in the western area of Lake St. Clair $\left(42.62941^{\circ} \mathrm{N}\right.$ and $-82.75462^{\circ} \mathrm{W}$, $3.4 \mathrm{~m}$ depth) and near the mouth of the Clinton River $\left(42.59482^{\circ} \mathrm{N}\right.$ and $-82.79232^{\circ} \mathrm{W}, 3.3 \mathrm{~m}$ depth) located south of Anchor Bay (Fig. 1). Five sediment cores were collected at each site using clear cellulose acetate butyrate tubes $(\sim 2 \mathrm{~m})$ with an inner diameter of $9.5 \mathrm{~cm}$. Each core was capped, labeled and kept in the shade and cold with dry ice during the field operations until they were stored vertically at $-80{ }^{\circ} \mathrm{C}$.

\section{Laboratory analyses}

\section{Sediment core preparation}

One frozen core from each site $(\mathrm{AB} 4=86 \mathrm{~cm}$ long, $\mathrm{CR} 4=58 \mathrm{~cm}$ long) was sliced in 2-cm increments with a horizontal band saw (Brooks et al. 2016). Peripheral sediment was removed from each sample to reduce bacterial contamination associated with core collection, and remaining frozen material was stored in Whirlpak ${ }^{\mathrm{TM}}$ bags. Cutting and cleaning implements were disinfected with $70 \%$ ethanol after each sediment section isolation. Sediment samples were thawed in a dark cold room $\left(4-8{ }^{\circ} \mathrm{C}\right)$ and individually homogenized prior to subsampling for fossil pigments. An aliquot was also dried $\left(24 \mathrm{~h}\right.$ at $\left.80{ }^{\circ} \mathrm{C}\right)$ for determination of water content before being ground with a mortar and pestle for subsequent analyses.

\section{Radionuclide dating}

About $25 \%$ of the mass of each sediment section was used for radiochemical analysis following Jweda and Baskaran (2011). ${ }^{210} \mathrm{~Pb}$ activities were measured using its progeny ${ }^{210} \mathrm{Po}$, assuming ${ }^{210} \mathrm{Po}$ and ${ }^{210} \mathrm{~Pb}$ were in secular equilibrium. Briefly, aliquots of $1.5 \mathrm{~g}$ dried and pulverized samples were taken up in Teflon digestion vessels with $10 \mathrm{~mL}$ each of concentrated $\mathrm{HF}, \mathrm{HNO}_{3}$ and $\mathrm{HCl}$ and $0.75 \mathrm{~mL}$ of ${ }^{209} \mathrm{Po}$ spike $\left(5.32 \pm 0.06 \mathrm{dpm} \mathrm{mL}^{-1}\right)$. The digested solutions were dried on an open hot plate and then taken up in $5 \mathrm{~mL}$ of $6 \mathrm{M} \mathrm{HCl}$. At this stage, most of the samples were completely dissolved and they were centrifuged if any residue was found. To the solution, $30 \mathrm{~mL}$ of distilled water was added and the sample containing Po was plated by spontaneous deposition onto a highpurity Ag disk. The disks were analyzed by alpha spectrometer with surface barrier detectors coupled to an Octete-PC (ORTEC Co.).

Gamma-emitting radionuclides $\left({ }^{137} \mathrm{Cs}\right.$ and $\left.{ }^{226} \mathrm{Ra}\right)$ were measured by placing $\sim 10 \mathrm{~g}$ of the dried and homogenized sediments into $10 \mathrm{~mL}$ counting vials and determining isotopic activities of ${ }^{137} \mathrm{Cs}$ and ${ }^{226} \mathrm{Ra}$ (for parent-supported ${ }^{210} \mathrm{~Pb}$ level) using a high purity germanium well detector coupled to a Canberra InSpector multi-channel analyzer. No background peaks were observed for any of the assayed radionuclides. The gamma ray detector was calibrated with sediment standards: IAEA-300 for ${ }^{137} \mathrm{Cs}(661.6 \mathrm{keV})$ and RGU-1 for ${ }^{226} \mathrm{Ra}$ (via ${ }^{214} \mathrm{~Pb}$ and ${ }^{214} \mathrm{Bi}$ at $352 \mathrm{keV}$ and $609 \mathrm{keV}$, respectively) obtained from the International Atomic Energy Agency. Typical resolution (full width at half maximum) of the detector was $1.3 \mathrm{keV}$ at $46 \mathrm{keV}$ and $\sim 2.2 \mathrm{keV}$ at $1.33 \mathrm{MeV}$ (Jweda and Baskaran 2011).

In a freshwater system where there are large-scale watershed changes, ${ }^{137} \mathrm{Cs}$ often provides a more reliable chronology (Baskaran et al. 2014 and the references cited therein) than excess ${ }^{210} \mathrm{~Pb}$-based $\left({ }^{210} \mathrm{~Pb}_{\mathrm{xs}}\right)$ chronology. Although the parent-supported ${ }^{210} \mathrm{~Pb}$ activity of ${ }^{226} \mathrm{Ra}$ remained constant $\left(1.2 \pm 0.1 \mathrm{dpm} \mathrm{g}^{-1}\right.$ dry mass) between 8 and $36 \mathrm{~cm}$ depth in AB4, ${ }^{226} \mathrm{Ra}$ activities increased below $36 \mathrm{~cm}$ burial depth to values between 1.8 and $3.9 \mathrm{dpm} \mathrm{g}^{-1}$. Such increased activity could reflect recent submarine groundwater discharge enriched in ${ }^{226} \mathrm{Ra}$ or changes in granulometric parameters. In addition, hydrological discharge of ${ }^{222} \mathrm{Rn}$ results in ${ }^{210} \mathrm{~Pb}_{\mathrm{xs}}$ activity can 
influence chronology and is another reason why ${ }^{137} \mathrm{Cs}$ inferred mass accumulation rate was used to approximate sediment dates. Both the linear and mass sedimentation rates were comparable using the methodologies of ${ }^{137} \mathrm{Cs}$ and ${ }^{210} \mathrm{~Pb}_{\mathrm{xs}}$ (Table 1) for each site. The timing of peak ${ }^{137} \mathrm{Cs}$ activity agreed with that provided by application of a constant flux:constant sedimentation (CFCS) model using the ${ }^{210} \mathrm{~Pb}_{\mathrm{xs}}$ activities, and this suggests that the timing of events in the last 70 years is likely accurately captured. The timing in the early twentieth century and prior is subject to possible errors associated with variable sediment flux and sedimentation associated with land clearance and approximate dates are provided in the text at 25-year intervals from 1860 to 1950 and at 5-year intervals after 1960 to take this into consideration.

\section{Elemental and isotopic analysis}

The sediment organic matter (SOM) content of samples was estimated by loss-on-ignition method, which included initial drying at $80{ }^{\circ} \mathrm{C}$ (dry mass mean $=1.65 \mathrm{~g}$, std. error $=0.02 \mathrm{~g}, \mathrm{n}=72$ ) for at least $24 \mathrm{~h}$ to remove water prior to combustion for $2 \mathrm{~h}$ in a muffle furnace at $550{ }^{\circ} \mathrm{C}$. Dried sediment was treated with $10 \% \mathrm{HCl}$ overnight at $50{ }^{\circ} \mathrm{C}$ to remove carbonates prior to isotopic analysis.

Carbon and nitrogen stable isotope values and their abundances were measured in bulk sediments following Fry (2007) using an automated Eurovector elemental analyzer (with one gas chromatography column) coupled to an Isoprime isotope ratio mass spectrometer. Isotopic results were reported using the standard delta $(\delta)$ notation with respect to an international standard (Vienna Peedee Belemnite and atmospheric $\mathrm{N}_{2}$ for carbon and nitrogen, respectively) and were used to infer historical changes in the sources (aquatic vs. terrestrial) of organic matter. Based on replicate isotopic standards, analytical precision was calculated at $\pm 0.3 \%$. Analysis of an alanine standard was used to calculate the $\% \mathrm{C}, \% \mathrm{~N}$, mass values, and $\mathrm{C}: \mathrm{N}$ ratios.

Total phosphorus (TP) was determined by drying duplicate sediment samples overnight $\left(\sim 80{ }^{\circ} \mathrm{C}\right)$ followed by ashing at $550{ }^{\circ} \mathrm{C}$ for $2 \mathrm{~h}$ (Andersen 1976). Samples were acidified (15 mL, $1 \mathrm{~N} \mathrm{HCl}$, $15 \mathrm{~min}$ ) to extract $\mathrm{P}$ and solutions were diluted to $100 \mathrm{~mL}$. The resulting solution was analyzed by the ascorbic acid method (American Public Health Association 1998) using a Genesys $10 \mathrm{~S}$ UV-Vis spectrophotometer (Thermo Fisher Scientific Inc, Walthman, MA). Bioavailable phosphorus (Bio-P) was extracted using Truog's solution (Truog 1930) on duplicate bulk dry sediments ( $\sim 80^{\circ} \mathrm{C}$ overnight $)$ and $\mathrm{P}$ in solution was quantified by the ascorbic acid method as above.

\section{Fossil pigments}

Sediments from each core slice were kept frozen until analysis at the University of Regina's Institute of Environmental Change and Society. Sediments were freeze dried and chlorophyll $a(\mathrm{chl} a)$, carotenoid, and derivative pigments from algae were extracted overnight at $-4{ }^{\circ} \mathrm{C}$ in a solution of acetone, methanol and water (80:15:5) following Leavitt and Hodgson (2001). Extracts were filtered through a $0.22 \mu \mathrm{m}$ pore PTFE filter, dried under $\mathrm{N}_{2}$ gas and re-dissolved in a standard injection solvent mixture (Leavitt and Hodgson 2001). Pigments were separated and quantified using an Agilent 1100 high performance liquid chromatographic (HPLC) system fitted with an ODS Hypersil column ( $5 \mu \mathrm{m}$ particle size) and photodiode array detector. Pigments were identified on the basis of spectral characteristics and chromatographic position relative to authentic standards commercially available from DHI Denmark. Pigment analysis was restricted to taxonomically-diagnostic carotenoids characteristic

Table 1 Linear sedimentation and mass accumulation rates obtained using ${ }^{210} \mathrm{~Pb}_{\mathrm{xs}}$ and ${ }^{137} \mathrm{Cs}$ techniques from samples collected in Anchor Bay and Clinton River, Lake St. Clair, Michigan

\begin{tabular}{|c|c|c|c|c|}
\hline Core & $\begin{array}{l}{ }^{210} \mathrm{~Pb}_{\mathrm{xs}} \text {-based } \\
\text { Linear sed. rate } \\
\left(\mathrm{cm} \text { year }{ }^{-1}\right)\end{array}$ & $\begin{array}{l}{ }^{137} \text { Cs-peak } \\
\text { Linear sed. rate } \\
\left(\mathrm{cm} \text { year }^{-1}\right)\end{array}$ & $\begin{array}{l}{ }^{210} \mathrm{~Pb}_{\mathrm{xs}} \text {-based } \\
\text { Mass accum. rate } \\
\left(\mathrm{g} \mathrm{cm}^{-2} \text { year }^{-1}\right)\end{array}$ & $\begin{array}{l}{ }^{137} \text { Cs-peak } \\
\text { Mass accum. rate } \\
\left(\mathrm{g} \mathrm{cm}^{-2} \text { year }^{-1}\right)\end{array}$ \\
\hline Anchor Bay-4 & 0.38 & 0.39 & 0.40 & 0.35 \\
\hline Clinton River-4 & 0.58 & 0.67 & 0.35 & 0.42 \\
\hline
\end{tabular}


of the following algal/cyanbacterial groups: diatoms, chrysophytes and some dinoflagellates (fucoxanthin), mainly diatoms (diatoxanthin), cryptophytes (alloxanthin), chlorophytes (pheophytin $b$ ), chlorophytes and cyanobacteria (lutein-zeaxanthin), filamentous or colonial cyanobacteria (myxoxanthophyll), Nostocales cyanobacteria (canthaxanthin), all cyanobacteria (echinenone), purple sulfur bacteria (okenone), and the major $a, b$, and $c$-phorbins (chlorophyll related compounds) and their derivatives, although not all compounds were detected in every sample. The ultraviolet radiation (UVR) index is an index of the depth of UV penetration (lake transparency) and was estimated by dividing the UVR absorbing compound by the sum of four carotenoids (alloxanthin, diatoxanthin and leutin-zeaxanthin) and then multiplying by 100 (Leavitt et al. 1997). Pigment concentrations were expressed as nmol pigment $\mathrm{g}^{-1}$ organic matter, as recommended by Leavitt and Hodgson (2001).

\section{Diatoms and fossil inferred phosphorus}

Thawed sediment samples ( $10 \mathrm{~g})$ were digested with concentrated nitric acid on a hot plate, rinsed to constant $\mathrm{pH}$ with deionized water, and an aliquot was mounted on slides with Naphrax ${ }^{\circledR}$ high resolution mounting medium (Acker et al. 2002a, b). Diatom valves were identified to the species level and enumerated with a Leica DMLB microscope at $1000 \times$ magnification until 500 valves were reached. Older samples from Anchor Bay $(n=22$, before ca. 1900) had low density of diatom remains and could not be accurately enumerated.

The diatom inferred total P (DI-TP) concentration in Anchor Bay and the Clinton River were calculated using relative abundances of diatom taxa in core sections and a weighted-average model based on species distributions identified by the USEPA's National Lakes Assessment, NLA (Stevenson et al. 2013). Herein the weighted average model was based on the ln-transformed TP optimum of diatom taxa with $\geq 5$ observations in a set of lakes in the National Lakes Assessment using methods of ter Braak and van Dam (1989). Lakes used in the model were limited to sites with similar maximum depth, morphology, elevation, maximum annual air temperature in watershed, annual maximum of monthly precipitation, $\mathrm{Ca}$ concentration, conductivity, latitude, and longitude to those of Lake St. Clair (Stevenson et al. 2013). The resulting model had a coefficient of determination $\left(\mathrm{r}^{2}\right)$ of 0.63 between measured and model inferred $\ln -\mathrm{TP}$ concentrations. The weighted average TP model was tested by cross validation using a randomly selected two-thirds of the lakes to develop the model and the other one-third of the lakes to test the model, resulting in an $r^{2}$ of 0.53 between measured and model inferred ln-TP concentrations.

\section{Statistical analyses}

Statistical analyses and data manipulations were performed in SAS 9.4 using an $\alpha=0.05$. Simple linear regression (SLR) was used to determine rates of change for SOM and DI-TP. Piecewise regression analysis was utilized to determine potential change points (i.e., change in slope) by using PROC NLIN on $\log _{10}$-transformed data. Piecewise regression analysis was conducted on two data sets (ca. prior to 1920 and ca. 1950-2010) for Anchor Bay because of the numerous slopes and on the entire time series data (ca. mid 1850s to present) for Clinton River. The slopes (betas) were examined prior to (beta1) and after (beta2) the change points (CP).

Exploratory analysis of how the combined fossil proxies

$\left(\log _{10}(\mathrm{x}+1)\right)$

of fossil pigments, organic matter, nutrients, and fecal indicator bacteria may co-vary over time at the two sites was conducted with a correlation matrix based on principal component analysis (PCA) with the PROC PRINCOMP statement. Complete data sets were used in a time series for Anchor Bay (ca. 1900 to present) and Clinton River (ca. 1920 to present). Measurements of genetic markers representing two fecal indicator organisms, Escherichia coli and Enterococci, were from Brooks et al. (2016). Both piecewise regression and PCA helped to assess the co-variation of sedimentary proxies.

\section{Results}

Sediment chronology and accumulation rates

The ${ }^{137}$ Cs profiles exhibited a pattern consistent with historical records of atmospheric atomic bomb testing (Fig. 2). Based on the 1963 global fallout peak of 
${ }^{137} \mathrm{Cs}$, the corresponding linear sedimentation rate for Anchor Bay was $0.39 \mathrm{~cm} \mathrm{y}^{-1}$ and for Clinton River was $0.67 \mathrm{~cm} \mathrm{y}^{-1}$ (Table 1). Using a constant flux:constant sedimentation (CFCS) model, the ${ }^{210} \mathrm{~Pb}_{\mathrm{xs}^{-}}$ based chronology appears to agree reasonably well with the ${ }^{137}$ Cs-peak based chronology (Table 1, ESM1). This is similar to an earlier study from the same watershed in which there was good agreement of ages based on ${ }^{210} \mathrm{~Pb}_{\mathrm{xs}}$-based CFCS-model and ${ }^{137} \mathrm{Cs}-$ peak based model on four sediment cores but with less reliability using the constant rate of supply (CRS) and constant initial concentration (CIC) age models (Jweda and Baskaran 2011). However, the presence of ${ }^{137} \mathrm{Cs}$ in samples deposited before 1952 (after the
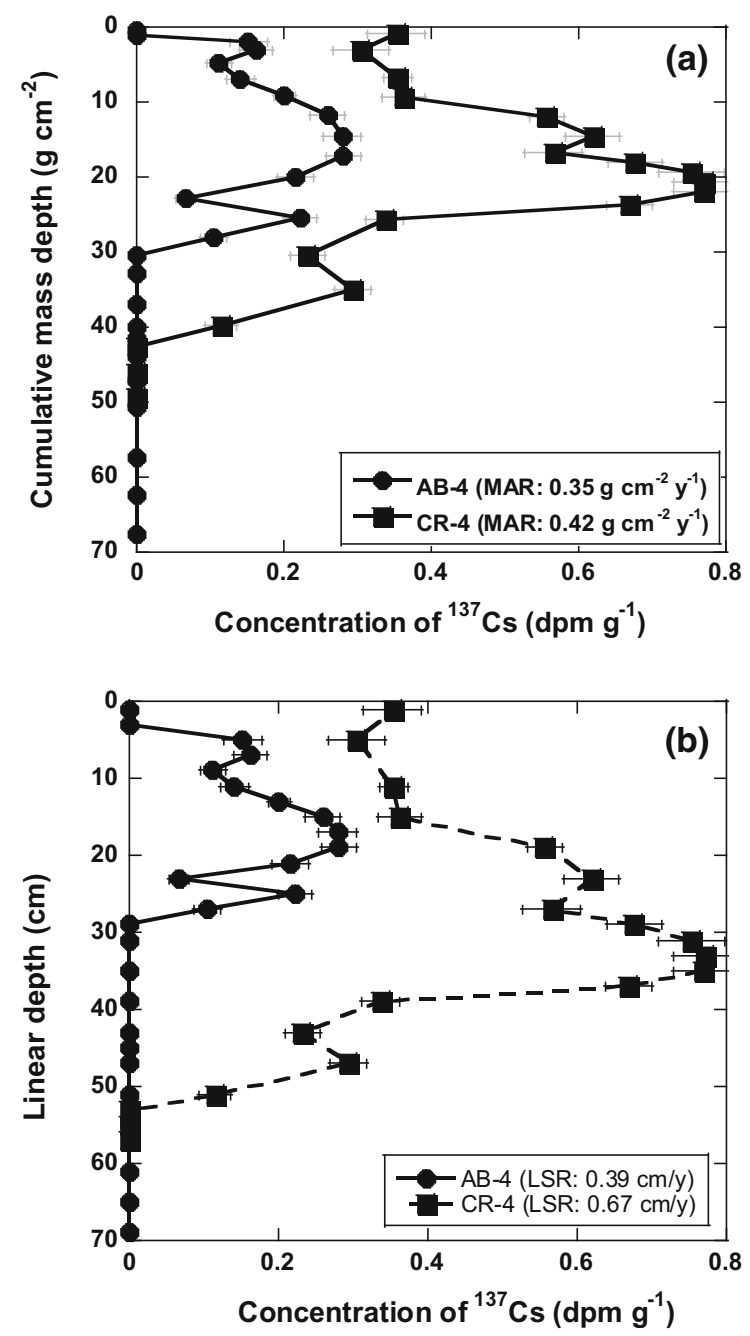

Fig. 2 Vertical profiles of a mass depth, b linear depth of ${ }^{137} \mathrm{Cs}$ concentration for Anchor Bay (AB) and Clinton River (CR). a Adapted from Brooks et al. (2016) first test in 1945, 18 tests were conducted in 1951) suggest some post-depositional mobility of ${ }^{137} \mathrm{Cs}$ by diffusion and/or physical and biological mixing, similar to patterns seen elsewhere in Lake St. Clair (Jweda and Baskaran 2011; Wang et al. 2017) and other freshwater systems (Davis et al. 1984). In both cores, the ${ }^{210} \mathrm{~Pb}_{\mathrm{xs}}$ activities in the upper $5-10 \mathrm{~cm}$ were not constant, which commonly result from bioturbation (ESM1 and ESM2), therefore the spread of the ${ }^{137} \mathrm{Cs}$ peak likely arose from resuspension of the uppermost sediment layers at the time of initial deposition (Fig. 2).

Measured inventories of ${ }^{210} \mathrm{~Pb}_{\mathrm{xs}}$ varied by a factor of two between the sites, with $73.8 \mathrm{dpm} \mathrm{cm}^{-2}$ at Anchor Bay site and $143 \mathrm{dpm} \mathrm{cm}^{-2}$ at Clinton River site. Both values are higher than what is expected from overhead atmospheric fallout for this watershed (Jweda and Baskaran 2011) and likely due to contribution from watershed erosional input. This difference may reflect variation in sediment focusing and/or differences in the amount of excessive influx of allochthonous material at the two sites. Peak ${ }^{137} \mathrm{Cs}$ activities were used at Anchor Bay to calculate a linear sedimentation rate of $0.39 \mathrm{~cm} \mathrm{y}^{-1}$ and mass accumulation rate of $0.35 \mathrm{~g} \mathrm{~cm}^{-2} \mathrm{y}^{-1}$ (Table 1). Earlier study from the same watershed showed that the comparison of ${ }^{137} \mathrm{Cs}$-peak based chronology and sediment ages derived from the ${ }^{210} \mathrm{~Pb}_{\mathrm{xs}}$-CFCS model were also better than those from CRS and CIC models (Jweda and Baskaran 2011). It has been shown that ${ }^{210} \mathrm{~Pb}$ based chronology can be impacted by large-scale changes in the watershed of a freshwater system, whereas ${ }^{137} \mathrm{Cs}$ peak can yield reliable chronology (Baskaran et al. 2014). Note that the penetration depth of ${ }^{137} \mathrm{Cs}$ corresponding to 1952 is less reliable due to postdepositional diffusion of ${ }^{137} \mathrm{Cs}$ and $>75 \%$ of the deposited ${ }^{137} \mathrm{Cs}$ in 1952 has decayed away (Wang et al. 2017).

Based on the ${ }^{137}$ Cs-peak and the sediment mass accumulation rate, the year of deposition of each sedimentary layer was calculated. The core at Anchor Bay spanned a wider range of ages (ca. mid-1700s to present) compared to Clinton River (ca. 1890-present), although a constant time interval of mid-1800s to present was used for the ecological interpretation herein. As noted above, high correspondence between ${ }^{210} \mathrm{~Pb}$ and ${ }^{137} \mathrm{Cs}$ chronologies after the mid-twentieth century inferred that modern events are likely accurately captured, whereas the comparative effects of 
earlier events (e.g., land clearance) are less accurately constrained (early twentieth century).

Elemental and isotopic stratigraphy

At Anchor Bay site, the SOM content increased rapidly from $\sim 7 \%$ to a maximum of $\sim 23 \%$ at the end of the nineteenth century, before declining to a plateau of $\sim 2 \%$ for almost 100 years (Fig. 3a). Since the late-1990s, SOM content in the Anchor Bay core increased by $0.75 \%$ per year (based from SLR, $\mathrm{r}^{2}=0.99, p=0.0003, \mathrm{n}=5$ ) to values near $10 \%$ in the uppermost deposits (Fig. 3a, Table 2). The sedimentary carbon $\left(\begin{array}{ll}\% & \mathrm{C}\end{array}\right)$ and nitrogen $\left(\begin{array}{ll}\% & \mathrm{~N}\end{array}\right)$ increased rapidly to a peak at the end of the nineteenth century (Fig. 3b, c), followed by a decline to stable levels until ca. 2000, after which \% C and \% $\mathrm{N}$ content increased to a secondary maximum (near 7 and $0.3 \%$, respectively). The $\% \mathrm{C}$ and $\% \mathrm{~N}$ of Anchor Bay site exhibited similar historical patterns to that of the SOM (Fig. 3a-c). Overall, C:N ratios at Anchor Bay increased from 14 in basal sediments to $\sim 20$ at the start of the twentieth century and then fluctuated thereafter (Fig. 3d).

Sedimentary organic matter content of Clinton River site varied little over time relative to Anchor Bay site (Fig. 3a, e). Overall, SOM at Clinton River ranged between $\sim 2$ and $9 \%$ in surficial sediments, with a notable increase ca. 1950 (Fig. 3e) and relatively constant values thereafter near 7-9\%. Sedimentary carbon and nitrogen at Clinton River site increased from $<0.5 \%$ in basal sediments to maxima in the surface sediments, with a sharper increase occurring since ca. 1950 (Fig. 3f, g). C:N ratios were variable in Clinton River (Fig. 3h) with a sustained increase above 20 after ca. 1980.

The $\delta^{13} \mathrm{C}$ and $\delta^{15} \mathrm{~N}$ values of the SOM tended to covary through time at both sites (Fig. 4). At Anchor Bay site, both $\mathrm{C}$ and $\mathrm{N}$ isotope values increased throughout the twentieth century, before declining after ca. 1985 (Fig. 4a, b). Values of $\delta^{13} \mathrm{C}$ values at Clinton River site increased from -28.5 to $-26 \%$ by the 1980 s, then declined to near baseline levels during the past 30 years (Fig. 4c), whereas $\delta^{15} \mathrm{~N}$ values at Clinton River site exhibited high variability during the early twentieth century before rising smoothly from a $\sim 2 \%$ minimum ca. 1930 to $\sim 4 \%$ at present (Fig. 4d).

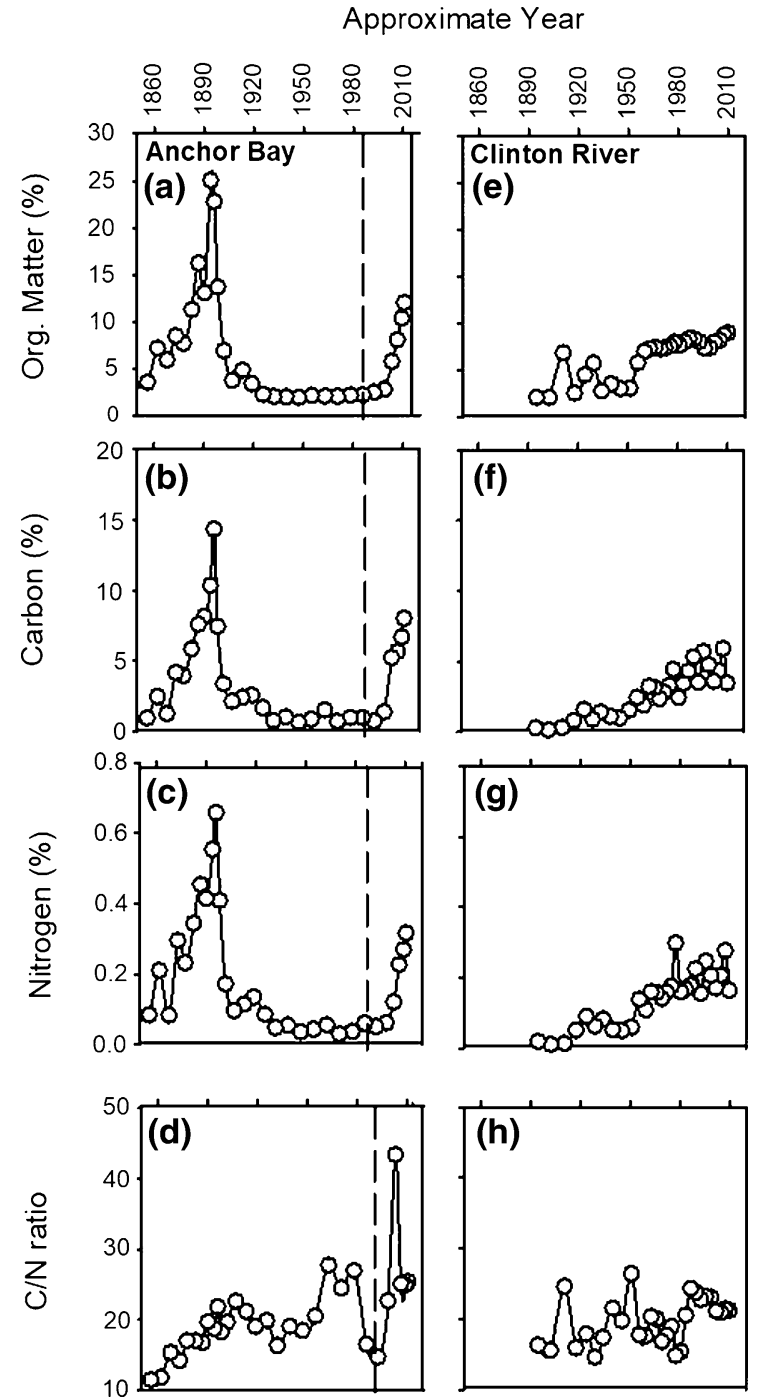

Fig. 3 Sedimentary percent organic matter (SOM; a, e), percent carbon $(\mathbf{b}, \mathbf{f})$, percent nitrogen $(\mathbf{c}, \mathbf{g})$, and $\mathrm{C}: \mathrm{N}$ ratios $(\mathbf{d}, \mathbf{h})$ from approximate years of 1850 to 2011 at two sites, Anchor Bay (left side, a-d), Lake St. Clair and of the Clinton River (right side, eh), Michigan, USA. Dashed line at ca. 1985 on Anchor Bay plots indicate the earliest time of arrival of the invasive Dreissena polymorpha and Dreissena rostriformis. b, c, f, $\mathbf{g}$ Adapted from Brooks et al. (2016). Approximate chronology derived from ${ }^{137} \mathrm{Cs}$ activities that are located in the Methods, Results, and ESM1

Mean sedimentary bioavailable phosphorus (Bio-P) and mean TP exhibited similar patterns over time at each site (Fig. 5). Bio-P decreased within older sediments to ca. 1900 in Anchor Bay, remained low and stable for $\sim 100$ years, then increased after ca. 1995 (Fig. 5a, Table 2), whereas TP concentrations 
Table 2 Piecewise regression results of temporal patterns of select sedimentary environmental indicators (Env. Ind.) from vibracores collected in Anchor Bay (ca. pre-1920 and ca. 1950-2010), Lake St. Clair and of Clinton River (ca. mid-1800s to present), Michigan, USA

\begin{tabular}{|c|c|c|c|c|c|c|}
\hline Site & Env. Ind & Par. & Est. & SE & $t$ value & $p$ value \\
\hline Anchor Bay & Org. Matter & $\mathrm{CP}$ & 1900 & 2.338 & 809.96 & $<0.0001$ \\
\hline \multirow[t]{14}{*}{ Pre-ca. 1920} & & Beta1 & 0.017 & 0.004 & 4.12 & 0.0021 \\
\hline & & Beta2 & -0.047 & 0.007 & -7.07 & $<0.0001$ \\
\hline & Bio-P & NA & & & & \\
\hline & $\mathrm{TP}$ & $\mathrm{CP}$ & 1900 & 4.349 & 431.0 & $<0.0001$ \\
\hline & & Beta1 & 0.013 & 0.005 & 2.63 & 0.0253 \\
\hline & & Beta2 & -0.016 & 0.005 & -3.02 & 0.0129 \\
\hline & DI TP & NA & & & & \\
\hline & B-caro & $\mathrm{CP}$ & 1900 & 3.852 & 490.5 & $<0.0001$ \\
\hline & & Beta1 & 0.004 & 0.003 & 1.2 & 0.255 \\
\hline & & Beta2 & 0.021 & 0.005 & 4.7 & 0.0007 \\
\hline & Chl $a$ & $\mathrm{CP}$ & 1900 & 4.68 & 404.3 & $<0.0001$ \\
\hline & & Beta1 & 0.004 & 0.003 & 1.47 & 0.17 \\
\hline & & Beta2 & 0.019 & 0.005 & 3.65 & 0.0038 \\
\hline & Pheo & NA & & & & \\
\hline Anchor Bay & Org. Matter & $\mathrm{CP}$ & 2000 & 0.8724 & 2289.03 & $<0.0001$ \\
\hline \multirow[t]{16}{*}{ post-ca. 1950} & Beta1 & 0.001 & 0.001 & 1.17 & 0.2788 & \\
\hline & & beta2 & 0.043 & 0.003 & 13.75 & $<0.0001$ \\
\hline & Bio-P & $\mathrm{CP}$ & 1995 & 3.6055 & 553.17 & $<0.0001$ \\
\hline & & Beta1 & -0.003 & 0.002 & -1.42 & 0.1991 \\
\hline & & Beta2 & 0.029 & 0.008 & 3.72 & 0.0075 \\
\hline & $\mathrm{TP}$ & NA & & & & \\
\hline & DI TP & NA & & & & \\
\hline & B-caro & $\mathrm{CP}$ & 1995 & 2.3802 & 838.12 & $<0.0001$ \\
\hline & & Beta1 & 0.008 & 0.003 & 3.09 & 0.0176 \\
\hline & & Beta2 & -0.049 & 0.009 & -5.53 & 0.0009 \\
\hline & Chl $a$ & $\mathrm{CP}$ & 1995 & 2.0032 & 995.76 & $<0.0001$ \\
\hline & & Beta1 & 0.024 & 0.004 & 6.73 & 0.0003 \\
\hline & & Beta2 & -0.081 & 0.012 & -6.62 & 0.0003 \\
\hline & Pheo & $\mathrm{CP}$ & 2000 & 2.6652 & 748.94 & $<0.0001$ \\
\hline & & Beta1 & 0.006 & 0.003 & 1.97 & 0.0897 \\
\hline & & Beta2 & -0.050 & 0.011 & -4.68 & 0.0023 \\
\hline \multirow[t]{11}{*}{ Clinton River } & Org. Matter & $\mathrm{CP}$ & 1980 & 18 & 109 & $<0.0001$ \\
\hline & & Beta1 & 0.005 & 0.001 & 5.450 & $<0.0001$ \\
\hline & & Beta2 & -0.004 & 0.003 & -1.180 & 0.2502 \\
\hline & Bio-P & $\mathrm{CP}$ & 1950 & 46 & 42 & $<0.0001$ \\
\hline & & Beta1 & 0.007 & 0.004 & 1.780 & 0.0865 \\
\hline & & Beta2 & -0.003 & 0.005 & -0.720 & 0.4776 \\
\hline & $\mathrm{TP}$ & $\mathrm{CP}$ & 1980 & 104 & 19 & $<0.0001$ \\
\hline & & Beta1 & 0.010 & 0.002 & 5.430 & $<0.0001$ \\
\hline & & Beta2 & -0.001 & 0.005 & -0.240 & 0.8152 \\
\hline & DI TP & $\mathrm{CP}$ & 1950 & 12 & 167 & $<0.0001$ \\
\hline & & Beta1 & 0.000 & 0.000 & 0.050 & 0.964 \\
\hline
\end{tabular}


Table 2 continued

\begin{tabular}{|c|c|c|c|c|c|c|}
\hline Site & Env. Ind & Par. & Est. & SE & $t$ value & $p$ value \\
\hline & \multirow{4}{*}{ B-caro } & Beta2 & 0.001 & 0.000 & 2.830 & 0.0091 \\
\hline & & $\mathrm{CP}$ & 2010 & 2 & 954 & $<0.0001$ \\
\hline & & Beta1 & 0.009 & 0.001 & 8.490 & $<0.0001$ \\
\hline & & Beta2 & 0.117 & 0.101 & 1.160 & 0.2585 \\
\hline & \multirow[t]{3}{*}{ Chl $a$} & $\mathrm{CP}$ & 2000 & 2 & 1019 & $<0.0001$ \\
\hline & & Beta1 & 0.010 & 0.001 & 13.150 & $<0.0001$ \\
\hline & & Beta2 & 0.063 & 0.020 & 3.190 & 0.0038 \\
\hline & \multirow[t]{3}{*}{ Pheo } & $\mathrm{CP}$ & 2000 & 8 & 238 & $<0.0001$ \\
\hline & & Beta1 & 0.014 & 0.002 & 8.720 & $<0.0001$ \\
\hline & & Beta2 & 0.036 & 0.068 & 0.530 & 0.6036 \\
\hline
\end{tabular}

Statistical parameters (Par.) include the $\mathrm{CP}=$ change point approximate date, Beta $1=$ slope of the line prior to the change point, and Beta $2=$ slope of the line after the change point. Org. Matter $=$ organic matter, Bio-P $=$ bioavailable phosphorus, TP $=$ total phosphorus, DI-TP = diatom-inferred total phosphorus B-Caro = beta carotene, chl $a=$ chlorophyll $a$, and Pheo = pheophytin a. $\mathrm{NA}=$ piecewise regression model was not applicable to that time-series data set. All data were $\log (\mathrm{x}+1)$ transformed

Estimated year (Est.) in bold indicates significant change point

increased slowly through the fossil record, with only two exceptional peaks (ca. 1900, near 2010; Fig. 5b, Table 2). At the Clinton River site, the mean Bio-P and

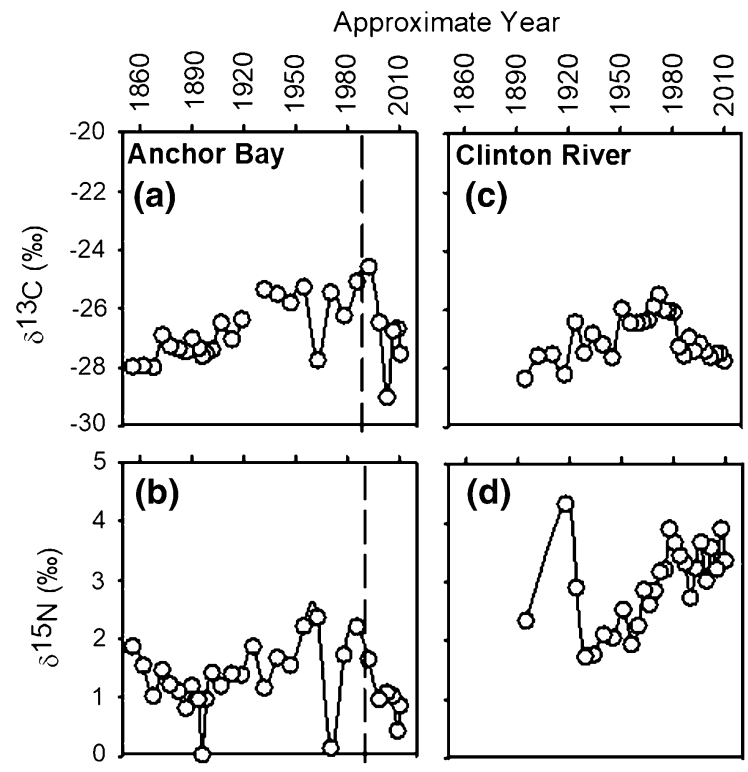

Fig. 4 Sedimentary $\delta^{13} \mathrm{C}(\mathbf{a}, \mathbf{c})$ and $\delta^{15} \mathrm{~N}$ nitrogen $(\mathbf{b}, \mathbf{d})$ from samples representing approximate years of 1850 to 2011 at two sites, and Anchor Bay (left side, a, b), Lake St. Clair, and Clinton River (right side, $\mathbf{c}, \mathbf{d}$ ) Michigan, USA. Dashed line at ca. 1985 on Anchor Bay plots indicate the earliest time of arrival of the invasive Dreissena polymorpha and Dreissena rostriformis. Chronology as Fig. 3
TP concentrations were low in the early 1900s and steadily increased over time to the present (Fig. 5d, e).

Diatom-inferred total phosphorus

Historical changes in diatom-inferred total phosphorus (DI-TP) concentrations indicated different nutrient histories at the two sites (Fig. 5c, f). In Anchor Bay site, DI-TP concentrations were stable during the twentieth century and into twenty-first century (SLR, $\mathrm{r}^{2}=0.009, p=0.68, \mathrm{n}=20$ ) (Fig. 5c, Table 2). At Clinton River site, the DI-TP concentrations were similar from the late-1800s to the mid-twentieth century, then increased significantly $(p=0.0091)$ until ca. 2010 (Table 2, Fig. 5f).

Fossil pigments

Analysis of fossil carotenoids, chlorophylls and derivatives indicate that the abundance of most algae and cyanobacteria increased during the twentieth century at the Anchor Bay and Clinton River sites, but that production declined after the mid-1990s at the Anchor Bay site alone (Fig. 6a, Table 2). For example, phototrophic abundance at Anchor Bay increased from low levels in the late nineteenth century to a maximum ca. 1990s before declining over fivefold thereafter (Fig. 6a). Concentrations of pigments representing 


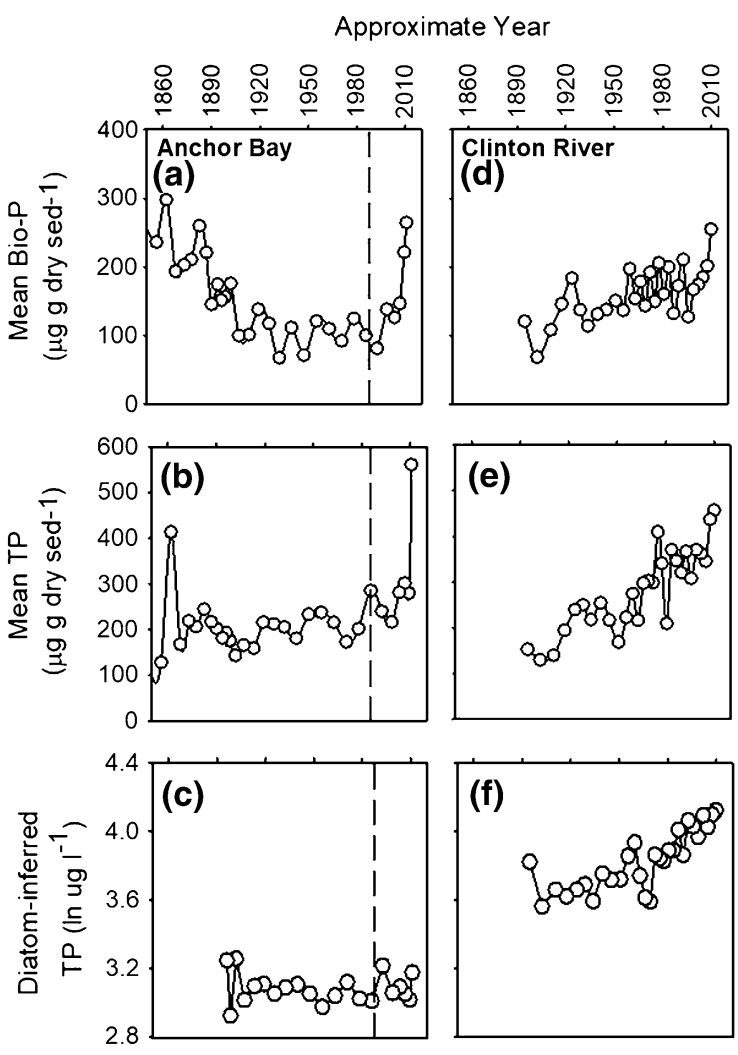

Fig. 5 Sedimentary mean bioavailable phosphorus (a, d), mean total phosphorus $(\mathbf{b}, \mathbf{e})$, and diatom-inferred TP $(\mathbf{c}, \mathbf{f})$ from approximate years of 1850 to 2011 at two sites, in Anchor Bay (left side, a-c), Lake St. Clair and of the Clinton River (right side, d-f), Michigan, USA. Dashed line at ca. 1985 on Anchor Bay plots indicate the earliest time of arrival of the invasive Dreissena polymorpha and Dreissena rostriformis. b, e Adapted from Brooks et al. (2016). Chronology as Fig. 3 diatoms (fucoxanthin) and cryptophytes (alloxanthin) increased sharply (40-100 and 13-25 $\mathrm{nmol} \mathrm{g}^{-1}$ org matter, respectively) after ca. 1980. Concentrations of all biomarker pigments declined since the 1990s and reached low values in the surficial sediments (Fig. 6a, Table 2). Pigments from chlorophytes (b-phorbins) and cyanobacteria (echinenone, canthaxanthin) were most common at Anchor Bay during the twentieth century, whereas the siliceous algae contributed the highest pigment levels after 1990. The chl a:pheophyin $a$ ratio started to increase during the 1970s, peaked in the 1990s, then decreased since that time. Similarly, water clarity as indicated by UVR index was high at Anchor Bay during the late-1800s, decreased to low levels until the 1940s, and increased to a transient peak during the 1970s (Fig. 6a).

Total pigment abundance (as $\beta$-carotene, phaeophytin $a$, chl $a$ ) at Clinton River site was low prior to ca. 1925, increased to a plateau at ca. 1950, then rose more sharply after the early 2000s (Fig. 6b, Table 2). Similar historical variation was also recorded for Clinton River pigments derived from cyanobacteria (echinenone, canthaxanthin), chlorophytes (chl $b$, pheophytin $b$ ), total bloom-forming taxa (lutein-zeaxanthin), diatoms (diatoxanthin) and cryptophytes (alloxanthin) (Fig. 6b). Overall, concentrations of pigments from chlorophytes and cyanobacteria were higher than those of other remaining taxonomic groups, with the exception of labile fucoxanthin (siliceous algae), which was most abundant in the uppermost sediments (Fig. 6b). Overall, the chl a:pheophytin a ratios were stable at Clinton River,

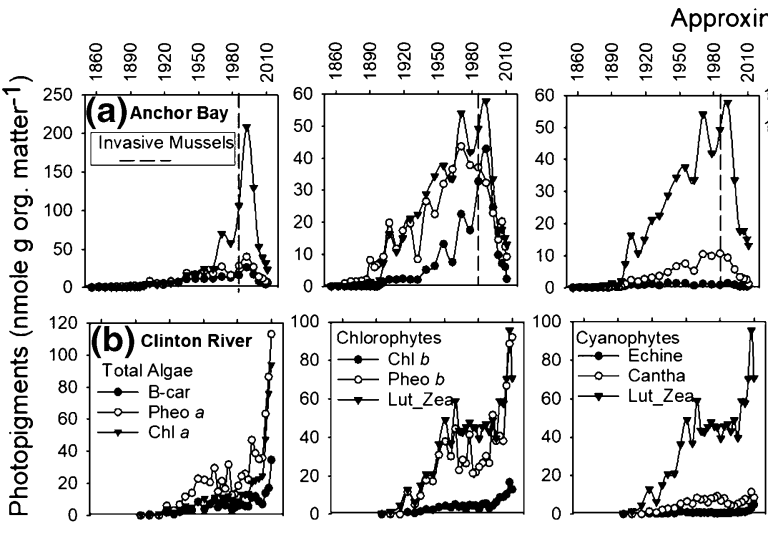

Fig. 6 Photopigment concentrations from approximate years of 1850 to 2011 of sediment cores collected at a Anchor Bay (top row), Lake St. Clair, b of the Clinton River (bottom row), Michigan, USA. Dashed line at ca. 1985 on Anchor Bay plots

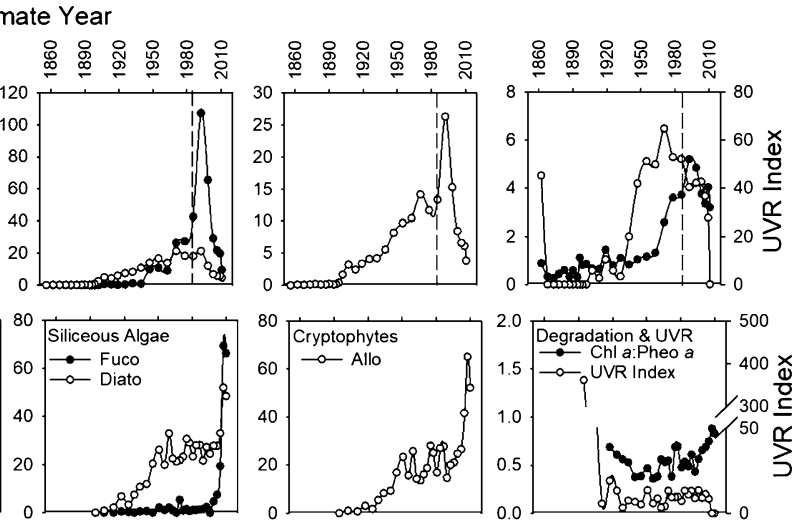

indicates the earliest time of arrival of the invasive Dreissena polymorpha and Dreissena rostriformis. UVR index is a water clarity indicator (depth of UV penetration within lakes). Chronology as Fig. 3 
suggesting limited changes in the preservation environment of the past 100 years, whereas the UVR index was briefly elevated in the early 1900s before declining to low levels since then (Fig. 6b).

\section{Co-variation of sedimentary proxies}

Principal component analysis showed that the first two components accounted for $71.0 \%$ and $74.2 \%$ of the historical environmental variability at Anchor Bay and Clinton River sites, respectively (Fig. 7a, b, Table 3). The historical trajectory at the Anchor Bay site included increasing fossil pigment concentrations along the first principal component (53.2\%) after ca. 1900 and until ca. 1950 (Fig. 7a). Since that time, the Anchor Bay site first experienced elevated TP and Bio-P content along the second principal component axis (17.8\%) (Fig. 7a, Table 3), before sharp declines
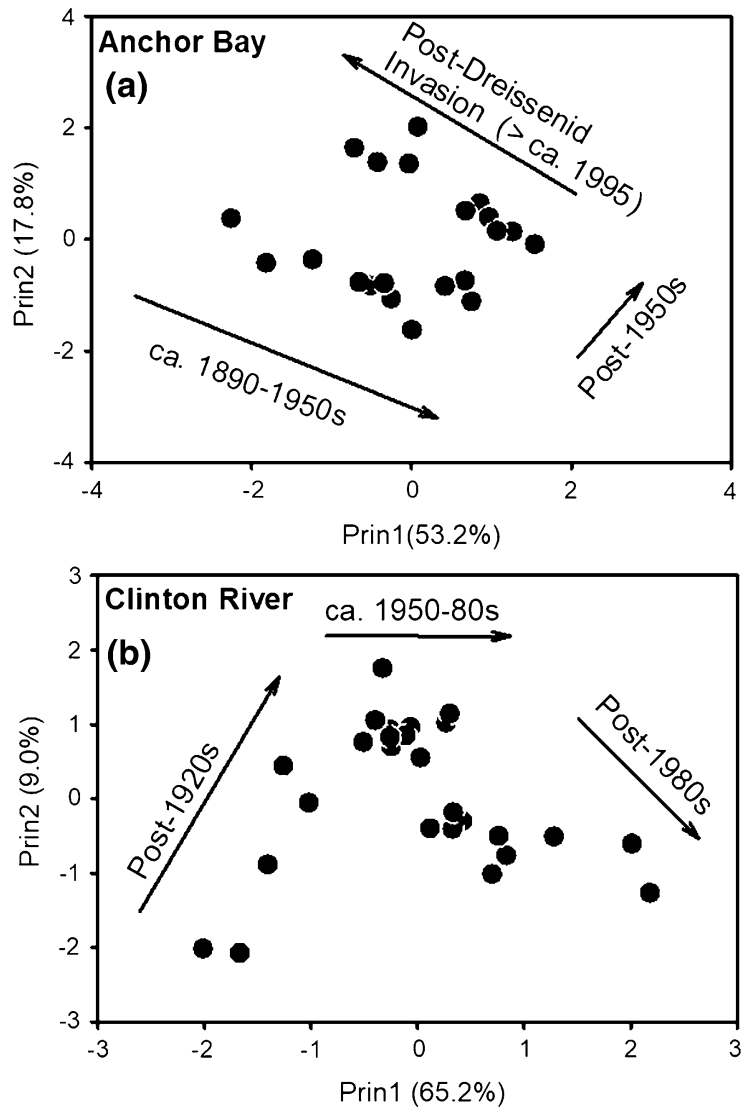

Fig. 7 Principal component analysis of historical environmental indicators representing approximate years of ca. 1890-2010 at two sites, a Anchor Bay, Lake St. Clair, b Clinton River, Michigan, USA
Table 3 Principal component scores (eigenvectors) for the historical environmental indicators (Env. Ind.) at two sites, in Anchor Bay, Lake St. Clair and of the Clinton River, Michigan, USA

\begin{tabular}{|c|c|c|c|c|}
\hline \multirow[t]{2}{*}{ Env. Ind } & \multicolumn{2}{|c|}{ Anchor Bay } & \multicolumn{2}{|c|}{ Clinton River } \\
\hline & Prin 1 & Prin2 & Prin1 & Prin2 \\
\hline Fuco & 0.23 & 0.30 & 0.22 & -0.17 \\
\hline Allo & 0.30 & 0.11 & 0.26 & 0.22 \\
\hline Diato & 0.30 & -0.03 & 0.25 & 0.27 \\
\hline Lut_Zea & 0.30 & -0.02 & 0.25 & 0.28 \\
\hline Cantha & 0.30 & -0.05 & 0.22 & 0.41 \\
\hline Chl $b$ & 0.28 & 0.13 & 0.27 & 0.05 \\
\hline Chl $a$ & 0.26 & 0.24 & 0.27 & -0.09 \\
\hline Echine & 0.21 & -0.32 & 0.23 & -0.09 \\
\hline Phaeo $b$ & 0.28 & -0.04 & 0.26 & 0.14 \\
\hline Pheo $a$ & 0.30 & 0.07 & 0.26 & 0.04 \\
\hline B-car & 0.30 & -0.01 & 0.25 & 0.08 \\
\hline Org. Matter & -0.25 & 0.25 & 0.20 & -0.01 \\
\hline $\mathrm{TP}$ & 0.05 & 0.32 & 0.21 & -0.21 \\
\hline Bio-P & -0.16 & 0.29 & 0.17 & -0.17 \\
\hline$\delta^{15} \mathrm{~N}$ & 0.15 & -0.21 & 0.11 & -0.29 \\
\hline$\delta^{13} \mathrm{C}$ & 0.07 & -0.29 & -0.06 & 0.54 \\
\hline $\mathrm{C}: \mathrm{N}$ & -0.01 & 0.37 & 0.13 & -0.03 \\
\hline Enterococcus spp. & 0.10 & 0.16 & 0.24 & -0.20 \\
\hline E. coli & 0.06 & 0.42 & 0.25 & -0.21 \\
\hline DI-TP & -0.07 & 0.07 & 0.23 & -0.18 \\
\hline
\end{tabular}

Full names of environmental indicators are listed in Table 2. All data were $\log (\mathrm{x}+1)$ transformed except $\delta^{13} \mathrm{C}$ and $\delta^{15} \mathrm{~N}$

in pigment concentrations after ca. 1990s despite continued increases in nutrient availability (Table 2). At the Clinton River site, the first principal component axis ( $65.2 \%$ of variance) was defined by gradients of fossil pigment concentration, total phosphorus, DI-TP, and organic matter content (Fig. 7b, Table 3), whereas the second principal component axis $(9.0 \%)$ was defined by a negative influence of total phosphorus loading. The temporal pattern indicates that the Bio-P and DI-TP increased from ca. 1950 to ca. 1980 and alterations in the concentrations of sedimentary organic matter, and TP after ca. 1980 (Fig. 7b, Table 2). 


\section{Discussion}

Analysis of diverse sediment proxies at two contrasting sites provide the first clear fossil evidence of the significant impacts of non-native Dreissena in Anchor Bay, Lake St. Clair, a pivotal ecosystem linking the upper and lower Laurentian Great lakes, as well as eutrophication, particularly at the Clinton River. Both sites recorded sustained increases in abundance of most algal and cyanobacterial groups during the twentieth century. However, site histories diverge sharply after invasion of Dreissena into Anchor Bay ca. 1995, with phytoplankton abundance declining $\sim 70 \%$, while SOM and Bio-P increased $200 \%$, within 10 years of invasion. The delay in response may be due to the spatial and temporal heterogeneity of $D$. polymorpha both in density and biomass combined with the local environmental conditions of Anchor Bay (Higgins et al. 2011). These findings provide new information on the long-term ecological changes of this region, including that nutrient enrichment and invasive bivalves were significant agents of change and builds off previous work by Brooks et al. (2016) that utilized the same cores for assessing long-term associations of anthropogenic and climatic variables with fecal indicator bacteria.

\section{Anchor Bay}

Paleolimnological analyses revealed that the ecological condition of Anchor Bay has experienced dramatic changes since ca. 1990 compared to the $\sim 100$ years prior and that these changes reflect the sequential effects of nutrient influx and exotic Dreissena invasion. Concentrations of most sedimentary components associated with phytoplankton production (SOM, TP, Bio-P, pigments) increased modestly during the twentieth century, reflecting the combined effects of forest clearance, agricultural development and urbanization. However, Dreissena are thought to have first entered the Lake St. Clair ecosystem in 1985 and, once well established, were efficient (with their high biomass and density, David et al. 2009; Nalepa et al. 1996) at removing phytoplankton biomass from the water column. Consistent with this narrative, sedimentary concentrations of the indicators of total phototroph abundance (chl $a$, pheophytin $a, \beta$-carotene) at Anchor Bay site declined sharply after ca. 1995, with chl $a$ declining from 200 to
$25 \mathrm{nmol} \mathrm{g}{ }^{-1}$ organic matter, despite the tendency for this labile compound to be over represented in surficial sediments (Leavitt and Hodgson 2001). Although the extent of pigment decline varied among biomarkers ( -60 to $-95 \%)$, uniform patterns of decline occurred during an interval when the pigment preservation environment was similar, as recorded by relatively stable Chl $a$ :pheophytin $a$ ratios (Leavitt and Hodgson 2001). In general, the magnitude of fossil pigment decline is similar to previous estimates of the reduction of pelagic primary production attributed to the suspension feeding of Dreissenia (Higgins and Vander Zanden 2010). Because fossil pigments integrate material from throughout the lake, we can infer that the decline in planktonic production was not offset by increased abundance of phytobenthos (benthic diatom data not shown), as seen in some shallow lakes undergoing critical transitions (McGowan et al. 2005). The decline in $\delta^{13} \mathrm{C}$ and $\delta^{15} \mathrm{~N}$ values post-Dreisenna invasion also suggests a reduction in pelagic primary production coupled with an increase in urbanization of the watershed (Leavitt et al. 2006; Savage et al. 2004).

Concomitant changes in sedimentary pigments, $\mathrm{P}$ fractions, and SOM suggest that phytoplankton consumed by Dreissena may have been deposited in shallow-water sediments as feces and pseudofeces (Auer et al. 2010; David et al. 2009; Higgins et al. 2008; Nalepa and Gauvin 1988; Nalepa et al. 1996). For example, the concentrations of bioavailable $\mathrm{P}$ and sedimentary organic matter tripled since ca. 1995 concomitant with establishment of $D$. polymorpha and $D$. rostriformis that entered the system around 1985-1988 (Griffiths 1993; Griffiths et al. 1991). These changes in conditions (fossil pigments, $\mathrm{P}$ fractions and SOM) were similar to those observed after Dreissena invasion of Saginaw Bay, Lake Huron (Fahnenstiel et al. 1995), Lake Simecoe, Ontario (Hawryshyn et al. 2012), and Green Bay, Lake Michigan (Qualls et al. 2007), suggesting that areas throughout the Great Lakes Basin were responding similarly to establishment of the exotic bivalves.

Forest and land clearance in support of agriculture also appeared to influence sediment character at Anchor Bay in Lake St. Clair (Brooks et al. 2016), although we recognize our chronology is less reliable at the base of the cores. For example, high organic matter loading to sediments (as SOM, \% C, \% N, Bio$\mathrm{P})$ was also observed during the late-1800s when urban 
expansion, forestry, and agricultural intensification led to deforestation and discharge from pulp mills (Meyers 2003; Schulte et al. 2007; Williams 1989). Similar patterns of organic matter conditions ca. 1900 were observed from sediment cores in the southern region of Lake Huron in the Province of Ontario (Meyers 2003). Consistent with this interpretation, $\mathrm{C}: \mathrm{N}$ ratios of the sediments increased from algal-like values ( $\sim 12: 1)$ to those characteristic of terrestrial vegetation ( $\sim 20: 1)$ during the late nineteenth and early twentieth centuries (Meyers 2003). Perennial submerged aquatic vegetation expanded their distribution in the lake by responding to the increased light levels produced by algal drawdown by $D$. polymorpha and could also influence these sedimentary proxy results by increasing organic matter and phototrophic pigment concentrations (Hunter and Simons 2004). However, despite marked effects of land-use practices, effects of Dreissena were detected in the macrophyterich basin of Lake St. Clair. Lastly, we did not observe increased light levels as expected with less pelagic primary production and instead the UVR index suggests light levels decreased since the invasion.

\section{Clinton River}

Fossil analyses provided evidence of human impacts at the Clinton River site as far back as ca. 1900, as indicated by the high sedimentary TP (measured and diatom-inferred) and increased $\delta^{15} \mathrm{~N}$ values (3-7\%) indicative of urbanization or animal wastes (Leavitt et al. 2006; Savage et al. 2004) as well as correlation of $\%$ TN with E. coli concentrations (Brooks et al. 2016). In general, $\delta^{13} \mathrm{C}$ and $\delta^{15} \mathrm{~N}$ values of SOM were within the ranges expected for a mixture of phytoplankton and terrestrial organic matter in the Great Lakes region (Lu et al. 2010; McCusker et al. 1999; Tenzer et al. 1999). However, the variable and high C:N ratios in Clinton River also suggest periodic influx of terrestrial material (woody or herbaceous) during much of the twentieth century (Meyers 2003).

Water quality indicated by sedimentary TP and Bio-P content at Clinton River site appeared to decline starting in the mid-twentieth century, likely reflecting the increased urbanization in metropolitan Detroit (Brooks et al. 2016). Elevated nutrient influxes from diffuse and point sources (Baustian et al. 2014) are suggested by increasing sedimentary content of both $P$ fractions after ca. 1950s (Figs. 3, 4, 5). Historical phosphorus fluctuations have been recorded throughout the Laurentian Great Lakes and globally; nutrient levels have tended to be moderate until the early 1950s, and then increased greatly because human population growth and intensified agricultural practices increased nutrient delivery to the coastal zone (Cordell et al. 2009; Meyers 2003).

Limited monitoring data from the Clinton River also confirms interpretations that high turbidity, phosphorus content, and phytoplankton abundance were observed during the 1990s in response to influx of nutrients, particularly from storm water runoff (Esman 2007; Michigan Department of Environmental Quality 1998). Furthermore, changes in fossil pigments are consistent with management concerns that water quality measures such as high TP and chl $a$ in the Clinton River and its spillway have continued to be degraded during the past 30 years (Brooks et al. 2016; Environmental Consulting and Technology 2007). In this study, application of diverse paleolimnological indicators provided essential management information on timing and magnitude of degradation in an Area of Concern that connects the Laurentian Great Lakes, which was not previously available.

\section{Conclusions}

Comparative paleolimnological analyses at two sites in a large lake ecosystem demonstrate that optimal management requires site-specific information on the causes and extent of environmental change. At Anchor Bay, water quality degradation arose initially from widespread land-use change, with algal and cyanobacterial abundance increasing over time, followed by rapid and profound declines in production within 10 years after the introduction of Dreissena. In contrast, water quality at the Clinton River tributary site has been influenced continuously by urban and agricultural development over 100 years, with more marked declines in water quality in the past 30 years. Together, these findings show that localized sitespecific histories are needed to account for spatial variability in regulatory mechanisms and focus effectively management strategies in large lake ecosystems.

Acknowledgements This work was supported in part by the National Science Foundation under Award No. EAR-1039122, NSERC Canada, Canada Foundation for Innovation, Province 
of Saskatchewan, University of Regina, Queen's University Belfast, and Canada Research Chair funding. We thank many people for their assistance with this project: Great Lakes Environmental Center, Inc. and Z. Geurin for helping collect sediment vibracores, B. Graff, G. Mavrommati, R. Ives, and T. Gim Aw for assisting in slicing and processing the sediment cores, M. Erickson (Michigan State University) for initial sediment C:N ratio analysis, Z. Quiñones-Rivera (University of Regina) for pigment analyses, S. Hunt for sediment phosphorus and LOI analyses, J. Zalack for diatom identification analysis, and lastly, H. Gandhi for stable isotope analyses. Thanks to T. Carruthers for reviewing earlier drafts of this manuscript and for the editors and anonymous reviewers that provided detailed comments to improve the clarity of the manuscript.

Open Access This article is licensed under a Creative Commons Attribution 4.0 International License, which permits use, sharing, adaptation, distribution and reproduction in any medium or format, as long as you give appropriate credit to the original author(s) and the source, provide a link to the Creative Commons licence, and indicate if changes were made. The images or other third party material in this article are included in the article's Creative Commons licence, unless indicated otherwise in a credit line to the material. If material is not included in the article's Creative Commons licence and your intended use is not permitted by statutory regulation or exceeds the permitted use, you will need to obtain permission directly from the copyright holder. To view a copy of this licence, visit http://creativecommons.org/licenses/by/4.0/.

\section{References}

Acker F, Russell B, Hagan E (2002a) Diatom cleaning by nitric acid digestion with a microwave apparatus. In: Charles D, Knowles C, Davis RS (eds) Protocols for the analysis of algal samples collected as part of the US Geological Survey national water-quality assessment program. The Academy of Natural Sciences, Patrick Center for Environmental Research-Phycology Section, Philadelphia, pp 13-42

Acker F, Russell B, Morales E (2002b) Preparation of diatom slides using Naphrax ${ }^{\mathrm{TM}}$ mounting medium. In: Charles D, Knowles C, Davis RS (eds) Protocols for the analysis of algal samples collected as part of the US Geological Survey national water-quality assessment program. The Academy of Natural Sciences, Patrick Center for Environmental Research-Phycology Section, Philadelphia, pp 13-42

American Public Health Association (1998) Standard methods for the examination of water and wastewater. APHAAWWA-WEF, Washington, DC, pp 4.146-144.148

Andersen J (1976) An ignition method for determination of total phosphorus in lake sediments. Water Res 10:329-331

Arbuckle KE, Downing JA (2001) The influence of watershed land use on lake $\mathrm{N}: \mathrm{P}$ in a predominantly agricultural landscape. Limnol Oceanogr 46:970-975

Auer MT, Tomlinson LM, Higgins SN, Malkin SY, Howell ET, Bootsma HA (2010) Great Lakes Cladophora in the 21st century: same algae-different ecosystem. J Great Lakes Res 36:248-255
Baskaran M, Nix J, Kuyper C, Karunakara N (2014) Problems with the dating of sediment core using excess ${ }^{210} \mathrm{~Pb}$ in a freshwater system impacted by large scale watershed changes. J Environ Radioact 138:355-363

Baustian M, Mavrommati G, Dreelin E, Esselman P, Schultze S, Qian L, Gim TA, Luo L, Rose J (2014) A one hundred year review of the socioeconomic and ecological systems of Lake St. Clair North America. J Great Lakes Res 40:15-26

Beeton AM (1969) Changes in the environment and biota of the Great Lakes. Eutrophication: causes, consequences, correctives. National Academy of Sciences, Washington, DC, pp 150-187

Bennett EM, Carpenter SR, Caraco NF (2001) Human impact on erodable phosphorus and eutrophication: a global perspective. Bioscience 51:227-234

Bolsenga SJ, Herdendorf CE (1993) The Lake Erie and Lake St. Clair handbook. Wayne State University, Detroit

Brooks YM, Baustian MM, Baskaran M, Ostrom NE, Rose JB (2016) Historical associations of molecular measurements of Escherichia coli and Enterococci to anthropogenic activities and climate variables in freshwater sediment cores. Environ Sci Technol 50:6902-6911

Carpenter SR, Caraco NF, Correll DL, Howarth RW, Sharpley AN, Smith VH (1998) Nonpoint pollution of surface waters with phosphorus and nitrogen. Ecol Appl 8:559-568

Cordell D, Drangert J-O, White S (2009) The story of phosphorus: global food security and food for thought. Global Environ Change 19292-305

David KA, Davis BM, Hunter RD (2009) Lake St. Clair zooplankton: evidence for post-dreissena changes. J Freshw Ecol 24:199-209

Davis RB, Hess CT, Norton SA, Hanson DW, Hoagland KD, Anderson DS (1984) ${ }^{137} \mathrm{Cs}$ and ${ }^{210} \mathrm{~Pb}$ dating of sediments from soft-water lakes in New England (USA) and Scandinavia, a failure of ${ }^{137} \mathrm{Cs}$ dating. Chem Geol 44:151-185

Environmental Consulting and Technology I (2007) Water quality sampling \& analysis: final report. Lake St. Clair Regional Monitoring Project Environmental Consulting and Technology, Inc., Clinton Township

Esman L (2007) The Michigan department of environmental quality biennial remedial action plan update for the Clinton River area of concern

Fahnenstiel GL, Lang GA, Nalepa TF, Johengen TH (1995) Effects of zebra mussel (Dreissena polymorpha) colonization on water quality parameters in Saginaw Bay, Lake Huron. J Great Lakes Res 21:435-448

Fry B (2007) Coupled N, C and S stable isotope measurements using a dual-column gas chromatography system. Rapid Commun Mass Spectrom 21:750-756

Griffiths RW (1993) Effects of zebra mussels (Dreissena polymorpha) on the benthic fauna of Lake St. Clair. In: Nalepa TF, Schloesser DW (eds) Zebra Mussels: biology, impacts, and control. Lewis Publishers, Boca Raton, pp 415-437

Griffiths RW, Schloesser DW, Leach JH, Kovalak WP (1991) Distribution and dispersal of the zebra mussel (Dreissena polymorpha) in the Great Lakes region. Can J Fish Aquat Sci 48:1381-1388

Hall SR, Mills EL (2000) Exotic species in large lakes of the world. Aquat Ecosyst Health Manag 3:105-135 
Harris GP, Vollenweider RA (1982) Paleolimnological evidence of early eutrophication in Lake Erie. Can J Fish Aquat Sci 39:618-626

Hawryshyn J, Rühland KM, Quinlan R, Smol JP (2012) Longterm water quality changes in a multiple-stressor system: a diatom-based paleolimnological study of Lake Simcoe (Ontario, Canada). Can J Fish Aquat Sci 69:24-40

Higgins SN, Vander Zanden MJ (2010) What a difference a species makes: a meta-analysis of dreissenid mussel impacts on freshwater ecosystems. Ecol Monogr 80:179-196

Higgins SN, Malkin SY, Todd Howell E, Guildford SJ, Campbell L, Hiriart-Baer V, Hecky RE (2008) An ecological review of Cladophora glomerata (Chlorophyta) in the Laurentian Great Lakes. J Phycol 44:839-854

Higgins SN, Vander Zanden MJ, Joppa LN, Vadeboncoeur Y (2011) The effect of dreissenid invasions on chlorophyll and the chlorophyll: total phosphorus ratio in north-temperate lakes. Can J Fish Aquat Sci 68:319-329

Hunter RD, Simons KA (2004) Dreissenids in Lake St. Clair in 2001: evidence for population regulation. J Great Lakes Res 30:528-537

International Joint Commission (2006) A guide to the Great Lakes water quality agreement: background for the 2006 governmental review

Jweda J, Baskaran M (2011) Interconnected riverine-lacustrine systems as sedimentary repositories: case study in southeast Michigan using ${ }^{210} \mathrm{~Pb}$ and ${ }^{137} \mathrm{Cs}$-based sediment accumulation and mixing models. J Great Lakes Res 37:432-446

Leach J (1972) Distribution of chlorophyll $a$ and related variables in Ontario waters of Lake St. Clair. In: Proceedings of 15 th conference of great lakes research, pp 80-86

Leach J (1991) Biota of Lake St. Clair: habitat evaluation and environmental assessment. Hydrobiologia 219:187-202

Leavitt PR, Hodgson DA (2001) Sedimentary pigments. In: Smol JP, Birks HJB, Last WM (eds) Tracking environmental changes using lake sediments. Kluwer, Dordrecht, pp 295-325

Leavitt PR, Vinebrooke RD, Donald DB, Smol JP, Schindler DW (1997) Past ultraviolet radiation environments in lakes derived from fossil pigments. Nature 388:457-459

Leavitt PR, Brock CS, Ebel C, Patoine A (2006) Landscapescale effects of urban nitrogen on a chain of freshwater lakes in central North America. Limnol Oceanogr 51:2262-2277

Levine SN, Lini A, Ostrofsky ML, Bunting L, Burgess H, Leavitt PR, Reuter D, Lami A, Guilizzoni P, Gilles E (2012) The eutrophication of Lake Champlain's northeastern arm: insights from paleolimnological analyses. J Great Lakes Res 38:35-48

Lu Y, Meyers PA, Johengen TH, Eadie BJ, Robbins JA, Han H (2010) $\delta^{15} \mathrm{~N}$ values in Lake Erie sediments as indicators of nitrogen biogeochemical dynamics during cultural eutrophication. Chem Geol 273:1-7

Mavrommati G, Baustian MM, Dreelin EA (2013) Coupling socioeconomic and lake systems for sustainability: a conceptual analysis using Lake St. Clair region as a case study. Ambio 43:275-287

McCrackin ML, Jones HP, Jones PC, Moreno-Mateos D (2017) Recovery of lakes and coastal marine ecosystems from eutrophication: a global meta-analysis. Limnol Oceanogr 62:507-518

McCusker EM, Ostrom PH, Ostrom NE, Jeremiason JD, Baker JE (1999) Seasonal variation in the biogeochemical cycling of seston in Grand Traverse Bay, Lake Michigan. Org Geochem 30:1543-1557

McGowan S, Leavitt PR, Hall RI, Anderson NJ, Jeppesen E, Odgaard BV (2005) Controls of algal abundance and community composition during ecosystem state change. Ecology 86:2200-2211

Meyers PA (2003) Applications of organic geochemistry to paleolimnological reconstructions: a summary of examples from the Laurentian Great Lakes. Org Geochem 34:261-289

Michigan Department of Environmental Quality (1998) Clinton River watershed remedial and preventive action plan: 1998 update and progress report

Nalepa TF, Gauvin JM (1988) Distribution, abundance, and biomass of freshwater mussels (Bivalvia:Unionidae) in Lake St. Clair. J Great Lakes Res 14:411-419

Nalepa TF, Hartson DJ, Gostenik GW, Fanslow DL, Lang GA (1996) Changes in the freshwater mussel community of Lake St. Clair: from Unionidae to Dreissena polymorpha in eight years. J Great Lakes Res 22:354-369

Pimentel D, Zuniga R, Morrison D (2005) Update on the environmental and economic costs associated with alien-invasive species in the United States. Ecol Econ 52:273-288

Qualls TM, Dolan DM, Reed T, Zorn ME, Kennedy J (2007) Analysis of the impacts of the zebra mussel, Dreissena polymorpha, on nutrients, water clarity, and the chlorophyll-phosphorus relationship in Lower Green Bay. J Great Lakes Res 33:617-626

Sanderson EW, Jaiteh M, Levy MA, Redford KH, Wannebo AV, Woolmer G (2002) The human footprint and the last of the wild: the human footprint is a global map of human influence on the land surface, which suggests that human beings are stewards of nature, whether we like it or not. Bioscience 52:891-904

Savage C, Leavitt PR, Elmgren R (2004) Distribution and retention of effluent nitrogen in surface sediments of a coastal bay. Limnol Oceanogr 49:1503-1511

Schelske CL, Stoermer EF, Conley DJ, Robbins JA, Glover RM (1983) Early eutrophication in the lower Great Lakes: new evidence from biogenic silica in sediments. Science 222:320-322

Schloesser DW, Nalepa TF, Mackie GL (1996) Zebra mussel infestation of unionid bivalves (Unionidae) in North America. Am Zool 36:300-310

Schulte LA, Mladenoff DJ, Crow TR, Merrick LC, Cleland DT (2007) Homogenization of northern US Great Lakes forests due to land use. Landscape Ecol 22:1089-1103

Selegean JPW, Kusserow R, Patel R, Heidtke TM, Ram JL (2001) Using zebra mussels to monitor in environmental waters. J Environ Qual 30:171-179

Stevenson RJ, Zalack JT, Wolin J (2013) A multimetric index of lake diatom condition based on surface-sediment assemblages. Freshw Sci 32:1005-1025

Tenzer GE, Meyers PA, Robbins JA, Eadie BJ, Morehead NR, Lansing MB (1999) Sedimentary organic matter record of recent environmental changes in the St. Marys River 
ecosystem Michigan-Ontario border. Org Geochem 30:133-146

ter Braak CJ, van Dam H (1989) Inferring pH from diatoms: a comparison of old and new calibration methods. Hydrobiologia 178:209-223

Truog E (1930) The determination of the readily available phosphorus of soils. Agron J 22:874-882

Turner RE, Rabalais NN (1994) Coastal eutrophication near the Mississippi river delta. Nature 368:619-621

Vanderploeg HA, Nalepa TF, Jude DJ, Mills EL, Holeck KT, Liebig JR, Grigorovich IA, Ojaveer H (2002) Dispersal and emerging ecological impacts of Ponto-Caspian species in the Laurentian Great Lakes. Can J Fish Aquat Sci 59:1209-1228
Vitousek PM, Aber JD, Howarth RW, Likens GE, Matson PA, Schindler DW, Schlesinger WH, Tilman DG (1997) Human alteration of the global nitrogen cycle: sources and consequences. Ecol Appl 7:737-750

Wang J, Baskaran M, Niedermiller J (2017) Mobility of ${ }^{137} \mathrm{Cs}$ in freshwater lakes: a mass balance and diffusion study of Lake St. Clair, Southeast Michigan, USA. Geochem Cosmochim Acta 218:323-342

Williams M (1989) Americans and their forests: a historical geography. Cambridge University Press, Cambridge

Publisher's Note Springer Nature remains neutral with regard to jurisdictional claims in published maps and institutional affiliations. 